\title{
DISCIPLINARY PROCESSES FOR SOUTH AFRICAN MAGISTRATES: REFLECTIONS ON THE MAGISTRATES ACT 90 OF 1993 AND THE LABOUR RELATIONS ACT 66 OF 1995
}

\section{Introduction}

An employment relationship creates certain rights and protection for the respective parties concerned. For example, an employee has the right not to be unfairly dismissed or subjected to unfair labour practices in the execution of his or her duties (s 185 of the Labour Relations Act 66 of 1995 (hereinafter "the LRA")). On the other hand, an employer has the right to lay down rules in order to regulate the conduct required from its employees (Grogan Workplace Law (2014) 151). The Code of Good Practice recognises this right of the employer: Dismissal (published under schedule 8 of the LRA (hereinafter "the Code")), which requires all employers to adopt disciplinary rules that establish the standard of conduct required from employees (item 3 of the Code). If an employee fails to adhere to the required rules or standards, the employer has recourse in the form of discipline (Grogan Workplace Law 149; see also Van Niekerk, Christianson, McGregor, Smit and Van Eck Law@work (2014) 89). Disciplinary action is usually initiated in response to poor work performance or unwarranted behaviour by workers and is aimed at restraining employees from behaving in a manner that could hamper production and the functioning of the organisation (Nel, Werner, Haasbroek, Poisat, Sono and Schultz Human Resources Management (2008) 140; Van der Bank, Engelbrecht and Strümpher "Perceived Fairness of Disciplinary Procedures in the Public Service Sector: An Exploratory Study" 20086 SAJHRM 12 2). When an employer exercises the right to discipline, regard must be had to the employee's right to be treated fairly. It is therefore important that disciplinary procedures should maintain a proper balance between the rights of the respective parties in the disciplining process.

The aim of this note is to compare the procedures for disciplining conventional employees in terms of the LRA with the procedures to discipline magistrates in terms of the Magistrates Act (90 of 1993 (hereinafter "the Magistrates Act")). The purpose of the comparison is to evaluate whether the disciplinary regime applicable to magistrates effectively ensures that they are appropriately and timeously disciplined when necessary in order to ensure a well-functioning judiciary. The note will commence with an outline of the legislative and regulatory framework of the respective disciplinary processes. This will be 
followed by an evaluation of whether the disciplinary regime governing magistrates contributes to a well-functioning judicial system. The note will conclude with recommendations regarding streamlined processes that would provide role players in the judiciary with certainty about the applicable remedies and the appropriate dispute resolution institutions where their disputes may be resolved.

\section{Disciplinary framework governing employees}

\section{Introduction}

The Constitution of the Republic of South Africa, 1996 (hereinafter "the Constitution") is the supreme law which provides for a number of labour rights. Some of these rights include the right to freedom of association in terms of section 18, the right to freely choose a trade, occupation and profession in terms of section 22 and the rights dealing with labour relations in terms of section 23 . The most important right provided by the Constitution, for the purposes of this note, is the right to fair labour practices guaranteed to everyone, in terms of section 23. Section 23 is entitled "labour relations" and in addition to the right to fair labour practices, it also provides for the right to strike and to form and join a trade union, and an employer's right to form and join an employers' organisation. This fundamental right has been given effect by the LRA, which expressly protects employees against unfair treatment. Section 1 of the LRA provides that one of the primary objectives of the Act is to give effect to and regulate the fundamental rights conferred by section 23 of the Constitution. Apart from the LRA, various other employment-related statutes have been enacted to provide protection to employees. The other main employment-related statutes that provide protection to employees include the Basic Conditions of Employment Act (75 of 1997), Employment Equity Act (55 of 1998), Compensation for Occupational Injuries and Diseases Act (130 of 1993), Unemployment Insurance Act (63 of 2001), Occupational Health and Safety Act (85 of 1993) and the Skills Development Act (97 of 1998).

Although the extensive protection afforded to employees by labour legislation does not provide immunity from being disciplined, the employer's right to discipline is limited by the LRA's codification of unfair dismissal and the Code (Finnemore Introduction to Labour Relations in South Africa (2006) 218). The Code is regarded as the basis for policy statements on disciplinary procedures. (Finnemore Introduction to Labour Relations in South Africa 220; Van der Bank et al 20086 SAJHRM 2). In principle, discipline and the consequences flowing therefrom, for example, sanctions, must take place within the broader framework of the right to fair labour practices. In this regard, the Code provides:

"While employees should be protected from arbitrary action, employers are entitled to satisfactory conduct and work performance from their employees." (item 1 of the Code). 


\section{Disciplinary procedures}

The first step in the disciplinary process would be for the employer to hold a disciplinary enquiry where the employee will have the opportunity to respond to the allegations made against him or her and to defend him- or herself (Finnemore Introduction to Labour Relations in South Africa 223). Should the employee be found guilty of misconduct at the enquiry, the employer is entitled to impose a sanction. The more common sanctions include warnings, transfers, demotions, suspensions and dismissal. The appropriate sanction will depend on the circumstances of each case and the relevant factors must be weighed up against each other. (Basson, Christianson, Garbers, le Roux, Mischke and Strydom Essential Labour Law (2005) 110; see also Nampak Corrugated Wadeville v Khoza (1999) 20 ILJ 578 (LAC) 584A-C). Relevant factors to take into account include the severity of the misconduct, the employee's disciplinary record and his or her length of service (item 3(5) of the Code; Grant and Behari "The Application of Consistency of Treatment in Dismissals for Misconduct" 201233 Obiter 145 145). If the circumstances and facts of the case permit, the employer may impose dismissal as a sanction, provided the employer complied with the requirements of fairness. Fairness entails that the employer may only dismiss an employee for a substantive reason. The substantive reasons for dismissal recognised by the Act are reasons relating to an employee's conduct or capacity or reasons based on the employer's operational requirements (s $188(1)(a)$ ). Fairness also requires that the employer must follow a fair procedure to effect the dismissal (s 188(1)(b)). The initiation of the disciplinary enquiry may satisfy the requirement of procedural fairness of the dismissal (see Avril Elizabeth Home for the Mentally Handicapped v CCMA (2006) 27 ILJ 1644 (LC) which set guidelines for a disciplinary enquiry to satisfy the requirement of fairness). Should the employer fail to comply with these requirements, the dismissal will be rendered unfair if the dismissal is not automatically unfair. The automatically unfair reasons for dismissal are listed in section 187 of the Act. If the dismissal is found to be automatically unfair, it means that the dismissal will be unfair by virtue of the reasons listed in section 187 and the employer will not be given an opportunity to justify the reason for the dismissal.

If an employee feels aggrieved by a dismissal, he or she is entitled to challenge the fairness thereof at the relevant dispute resolution institution ( $\mathrm{s}$ 191(1)(a)). The employee may refer a dispute to the bargaining council if the parties to the dispute fall within the scope of the relevant council (s 191(1)(a)(i)). If no council has jurisdiction over the dispute, the employee may refer the dispute to the Commission for Conciliation, Mediation and Arbitration (s 191(1)(a)(ii)). The dispute must be lodged within 30 days from the date of the dismissal or since the date the employer made a final decision to dismiss the employee (s 191(1)(b)(i)). In terms of section 191(2), the employee may still be allowed to refer a dispute where the time limits for referral have expired. 
The LRA furthermore sets out the burden of proof in dismissal disputes by requiring the employee to prove the dismissal (s 192(1)). In other words, the employee must prove that he or she was indeed dismissed. Conduct that constitutes dismissal is defined in section 186 of the Act. If a dismissal has been established, the burden shifts to the employer to show that the dismissal was fair (s 192(2)). As stated above, if the employer cannot satisfy the burden of proof, the dismissal will be regarded as unfair and this will entitle the employee to certain remedies. The specified remedies for unfair dismissal in terms of the LRA are reinstatement, re-employment or compensation (s 193(1)(a)-(c)). From the wording of the Act, it can be inferred that reinstatement and re-employment are the primary remedies available to an employee in the case of unfair dismissal. The LRA states that the Labour Court or the arbitrator must impose reinstatement or re-employment unless there are particular circumstances that justify the award of compensation. In terms of section 193(2)(a)(d) the particular instances where compensation will be the appropriate remedy include the consideration whether the employee wants to be reinstated or re-employed, whether a continued employment relationship would be intolerable, the practicality for the employer to reinstate or re-employ the employee and if the dismissal is only unfair by virtue of the employee having failed to follow a fair procedure. Furthermore, the LRA limits the amount of compensation that may be awarded to an employee. It provides that in the case of unfair dismissal, an employee will be entitled to compensation of up to 12 months' remuneration (s 194(1)). If the dismissal was automatically unfair, the compensation awarded may not exceed 24 months' remuneration (s 194(3)).

The above provisions of the LRA provide employers with peace of mind that their business standards and integrity can be maintained. Conversely, employees have certainty that their fundamental right to fair labour practices cannot be undermined by employers. In this regard, the LRA strikes a balance between the rights of employers and employees and ensures efficiency and certainty in the resolution of disputes arising in the course and scope of employment. The next section provides an outline of the disciplinary procedures applicable to magistrates should they not maintain the reasonable standards expected of them. This is followed by an evaluation of whether these procedures also ensure efficiency and certainty in the resolution of disputes arising in the course of magistrates executing their duties.

\section{Disciplinary framework governing magistrates}

\section{Introduction}

The Constitution does not provide for labour relations, similar to section 23, pertaining to magistrates specifically. It is worth noting that section 23(1) affords the right to fair labour practices to "everyone" and not only to "employees". The Supreme Court of Appeal previously held that soldiers who are not employees in 
terms of the LRA might rely on their constitutional right to fair labour practices (Murray v Minister of Defence 2009 (3) SA 130 (SCA)). This was also the High Court's view in Reinecke $v$ The President of South Africa ((unreported) 2012-0904 case number 25705/2004 par 44). In the latter case, the aggrieved magistrate claimed and was awarded a substantial amount of contractual damages on the basis that the chief magistrate repudiated the contract of employment between the parties by making the claimant's continued employment intolerable. On appeal (President of SA v Reinecke 2014 (3) SA 205 (SCA) (hereinafter "Reinecke")), the Supreme Court of Appeal rejected the magistrate's claim and did not make reference to his constitutional rights. The matter was also never heard by the Constitutional Court and therefore, it remains uncertain whether magistrates are protected against unfair labour practices.

The only reference in the Constitution regarding labour-related matters pertaining to magistrates specifically relates to the appointment of judicial officers in terms of section 174. It is provided that judicial offers, other than judges (eg, magistrates) must be appointed in terms of an Act of Parliament. It is provided that the relevant Act must ensure that the appointment, promotion, transfer, dismissal of, or disciplinary steps against, these judicial officers take place without fear, favour or prejudice (s 174(7)). The Magistrates Act has been enacted to give effect to this constitutional provision. The preamble to the Act states that it was enacted to regulate, amongst other things, the appointment and remuneration of, and vacation of office by, magistrates. Prior to the enactment of the Magistrates Act, magistrates held the status of employees and were appointed by the Minister of Justice (s 9 of the Magistrates' Courts Act 32 of 1944). Their conditions of service, retirement, remuneration, discipline, transfer, promotion and dismissals were regulated by the provisions of the Public Service Act 111 of 1984 (repealed) (in this regard see also Reinecke par 8). Magistrates were statutorily removed from the public service in order to establish an independent judiciary (Franco and Powell "The Meaning of Institutional Independence in Van Rooyen v The State" 2004121 SALJ 562 567).

It is also worth noting that even though historically magistrates were employees, they were never covered by the protection of the LRA. The predecessor of the current LRA excluded public servants from its scope and application (s 2 of the LRA 28 of 1956 (repealed); see also Grogan Collective Labour Law (2007) 6). Since the removal of magistrates from the public service, the Magistrates Act is the primary Act providing for employment-relatedprotection for magistrates. The Act established the Magistrates Commission (hereinafter "the Commission"), in terms of section 2, which is required to ensure, amongst other things, that disciplinary steps taken against magistrates take place without favour or prejudice (s 4). 


\section{Disciplinary procedures}

The disciplinary procedures for magistrates in the case of misconduct are set out in part five of the regulations in terms of the Act. Section 16 provides that the Minister may make regulations regarding, inter alia, the requirements for disciplinary steps against the magistrates. Regulation 25 contains the general provisions regarding misconduct and in essence, describes the circumstances in which a magistrate may be accused of misconduct. These include, but are not limited to, situations when the magistrate is found guilty of an offence contravenes a provision of the regulations, is negligent in the performance of duties, and refuses to execute a lawful order.

When there are allegations of misconduct against a magistrate, it is required that a preliminary investigation be conducted. This investigation may be held by another magistrate or an investigation officer. The procedures for the preliminary investigation are set out in regulation 26 . If the magistrate is found guilty or has admitted guilt, the Minister may suspend or relieve (relieve, remove and dismiss bears in essence the same meaning, eg, s 174(7) of the Constitution refers to the dismissal of magistrates as opposed to removal) such magistrate from office (regulation 26(17)). If the Minister finds that the conduct does not warrant suspension or removal, any of the following sanctions, in terms of regulation 26(17), may be imposed:

(a) caution or reprimand;

(b) withholding of translation to a higher salary scale or promotion to a higher post for a period not exceeding five years;

(c) transfer;

(d) a fine not exceeding R10 000; and

(e) a postponement of the decision to impose any of the listed sanctions, with or without conditions, for a period of 12 calendar months.

An aggrieved magistrate who is not satisfied with being found guilty of misconduct by the presiding officer may file a grievance with the Commission within 21 days after the conviction (regulation 26(17)). The grievance procedures set out the route that an aggrieved magistrate must take in order to have any dispute resolved. The grievance procedures are contained in regulations 31-33. These relate to disputes where a magistrate is dissatisfied with an official act or omission. Generally, the magistrate must first approach the head of the office, then the Commission and finally the Minister. The Minister makes the final decision and will inform the magistrate thereof in writing.

If the conduct of the magistrate warrants removal or suspension as a sanction, the procedures for such sanctions must be carried out in accordance with the provisions of the Act (s 13). The Act provides that the Commission may make recommendations to the Minister regarding the suspension of a 
magistrate. After considering the recommendations of the Commission, the Minister may provisionally suspend a magistrate. It is furthermore required that Parliament must pass a resolution to confirm or lift the suspension (s 13(3)). If the Commission recommends that a magistrate be removed from office, the Minister is obliged to suspend the magistrate or confirm the suspension if the magistrate had been provisionally suspended. The Parliament is then required to pass a resolution as to whether or not the restoration of the magistrate into office is recommended (s 13(4)(c)).

Despite the above procedures and the provision of the Act stipulating that Parliament must pass the relevant resolution as soon as reasonably possible (s $13(3)(c))$, this has not been the case in practice. The Commission expressed concern that the cases of misconduct against magistrates are not timeously resolved. One of the cases before the Commission was a magistrate who had been found guilty of murder and provisionally suspended in 2011, but whose suspension had not yet been confirmed by Parliament (Hartley "Delays-inCases-against the Magistrates Bothers Committee" 29 October 2014 http://www.bdlive.co.za/national/law/2014/10/29/delays-in-cases-against-

magistrates-bothers-committee (accessed 2015-07-14)). Another matter concerned the provisional suspension of a magistrate where the matter remained unresolved for 10 years (Hartley 29 October 2014 http://www.bdlive.co.za/national/law/2014/10/29/ delays-in-cases-againstmagistrates-bothers-committee).

\section{$4 \quad$ Analysis of the respective procedures}

The respective disciplinary procedures for conventional employees and magistrates differ in many respects. Some of these differences include the remedies for an unwarranted dismissal. As stated above, employees are entitled to specified remedies in terms of the LRA. The regulations in terms of the Magistrates Act do not provide for remedies in case of an unwarranted dismissal. It has been held that an aggrieved magistrate ought to find remedies in terms of the administrative law (Reinecke par 17), with the Promotion of Administrative Justice Act 3 of 2000 being the principal Act.

Another difference is that the Magistrates Act does not provide for specialised institutions for the resolution of disputes, as the LRA does. The dispute resolution institutions established by the LRA are aimed at ensuring expediency and efficiency, amongst other things (Benjamin "Conciliation, Arbitration and Enforcement: The CCMA's Achievements and Challenges" 200930 ILJ 26 46). The procedures to resolve disputes in terms of the Magistrates Act are lengthy and complex and give rise to delays. Delays in disciplinary procedures can have many consequences. For example, the person subjected to discipline may be under the impression that his or her conduct is not of such a serious nature. This is so because the greater the period between the occurrence of the offence and the eventual discipline, the less likely it is for the offender to realise the link 
between the unsatisfactory conduct and the application of discipline (Van der Bank Van der Bank et al 20086 SAJHRM 7). A further consequence of the delays in disciplining magistrates is that the public is likely to lose confidence in the magistracy if it appears that appropriate action is not being taken against magistrates who make themselves guilty of misconduct.

In light of the above, it is submitted that the disciplinary procedures applicable to magistrates are not as effective and efficient as the disciplinary procedures applicable to other employees in terms of the LRA. This raises the question as to the possibility of making the procedures in terms of the LRA applicable to magistrates in order to ensure a well-functioning judiciary. The answer lies in the fact that the provisions of the LRA are only applicable to employees.

Although the Supreme Court of Appeal in Reinecke acknowledged that an employment relationship exists between the aggrieved magistrate and the State, the court was not willing to pronounce whether the LRA is applicable to magistrates. It, therefore, remains uncertain whether the disciplinary mechanisms and principles established by the LRA could be made applicable to magistrates.

Previously the Labour Court held that magistrates are not employees because it would infringe upon the principle of judicial independence (Khanyile $v$ CCMA 2004 ILJ 2348 (LC)). However, in Reinecke, the Supreme Court of Appeal noted that if magistrates were to have status as employees it would not impede judicial independence (Reinecke par 7).

\section{Conclusion}

In their quest for justice, the majority of South Africans will be introduced to the judicial system through the Magistrates' courts (Van Dijkhorst "The Future of the Magistry" 200013 Advocate 39 42). In this regard, it has been stated that:

"Magistrates tend to shape the impressions and perceptions of litigants, witnesses and onlookers of the administration of justice. It is in the Magistrates court that admiration is earned and respect is lost" (Hoexter and Olivier The Judiciary in South Africa (2014) 319; see also Van Dijkhorst 200013 Advocate 42).

The delays in effectively resolving employment disputes of magistrates result in delays in court proceedings because magistrates who are on suspension will not be able to perform their judicial duties. These delays may impact upon judicial independence because they destroy the public's confidence in the judiciary (Pharmaceutical Society of South Africa (Pty) Ltd: New Clicks South Africa (Pty) Ltd v Minister of Health: Tshabalala-Msimang NO 2005 (3) SA 238 (SCA) 260G-261H; National Director of Public Prosecutions v Naidoo 2011 (1) SACR 336 (SCA)).

The inclusion of magistrates in the scope and application of the LRA is supported. This will provide clarity to magistrates regarding their appropriate 
remedies as well as to presiding officers regarding the appropriate relief they are authorised to grant to an aggrieved magistrate. The LRA makes provision for specific remedies in case of unfair dismissal and unfair labour practices and, a presiding officer may not make an award beyond those remedies. The provision of specified and limited remedies could assist presiding officers in dispute resolution with guidance as to the appropriate relief. It seems that the significant amount of damages claimed by the aggrieved magistrate in Reinecke contributed to the court's decision to reject the claim. (Van Eck and Diedericks "Are Magistrates without Remedy in terms of Labour Law? President of SA v Reinecke 2014 (3) SA 205 (SCA); (2014) 35 ILJ 1585 (SCA)" 201435 ILJ 2700 2708).

Also, in light of the important role that magistrates fulfil and the image they represent to the public, it is imperative that the public confidence in the judicial system is fostered and maintained. Making the tailor-made procedures established by the LRA available to magistrates will not necessarily infringe on the constitutionally guaranteed principle of judicial independence. It is submitted that it will not only provide clarity to magistrates regarding their remedies, but it will also ensure that they are appropriately and timeously disciplined when need be in order to ensure a well-functioning judiciary.

Leana Diedericks

University of Pretoria 